Am. Midl. Nat. 160:386-399

\title{
Use and Selection of Bridges as Day Roosts by Rafinesque's Big-Eared Bats
}

\author{
FRANCES M. BENNETT ${ }^{1}$ \\ Department of Forestry and Natural Resources, Institute of Environmental Toxicology, Clemson University, \\ Pendleton, South Carolina 29670 \\ SUSAN C. LOEB ${ }^{2}$ \\ USDA Forest Service, Southern Research Station, Clemson, South Carolina 29634
}

MARY S. BUNCH

South Carolina Department of Natural Resources, Pendleton, 29670

AND

WILLIAM W. BOWERMAN

Department of Forestry and Natural Resources, Institute of Environmental Toxicology, Clemson University, Pendleton, South Carolina 29670

\begin{abstract}
Rafinesque's big-eared bats (Corynorhinus rafinesquii) use bridges as day roosts in parts of their range, but information on bridge use across their range is lacking. From May to Aug. 2002 we surveyed 1129 bridges (12.5\%) within all 46 counties of South Carolina to determine use and selection of bridges as day roosts by big-eared bats and to document their distribution across the state. During summer 2003, we visited 235 bridges in previously occupied areas of the state to evaluate short-term fidelity to bridge roosts. We found colonies and solitary big-eared bats beneath 38 bridges in 2002 and 54 bridges in 2003. Construction type and size of bridges strongly influenced use in both years; bats selected large, concrete girder bridges and avoided flat-bottomed slab bridges. The majority of occupied bridges (94.7\%) were in the Upper and Lower Coastal Plains, but a few bridges (5.3\%) were located in the Piedmont. Rafinesque's big-eared bats were absent beneath bridges in the Blue Ridge Mountains. We established new records of occurrence for 10 counties. In the Coastal Plains, big-eared bats exhibited a high degree of short-term fidelity to roosts in highway bridges. For bridges that were occupied at least once, mean frequency of use was $65.9 \%$. Probability of finding bats under a bridge ranged from 0.46 to 0.73 depending on whether the bridge was occupied in the previous year. Thus, bridges should be inspected three to five times in a given year to determine whether they are being used. Regional bridge roost surveys may be a good method for determining the distribution of C. rafinesquii, particularly in the Coastal Plains, and protection of suitable bridges may be a viable conservation strategy where natural roost sites are limited.
\end{abstract}

\section{INTRODUCTION}

Rafinesque's big-eared bat (Corynorhinus rafinesquii) is found in the southern and midwestern United States (Fig. 1) and is one of the least studied bats in North America (Harvey et al., 1999). Despite having a relatively widespread distribution, this species is considered uncommon and is recognized as a species of special concern across most of its range (Hurst and Lacki, 1999; Martin et al., 2002). However, because Rafinesque's big-eared bats are not easily captured or detected with standard methods (e.g., mist nets, acoustic

\footnotetext{
${ }^{1}$ Present Address: Fish and Wildlife Branch, Saskatchewan Environment, 3211 Albert Street, Regina, SK S4S 5W6, Canada

${ }^{2}$ Corresponding author: e-mail: sloeb@fs.fed.us; Phone: 864-656-4865
} 


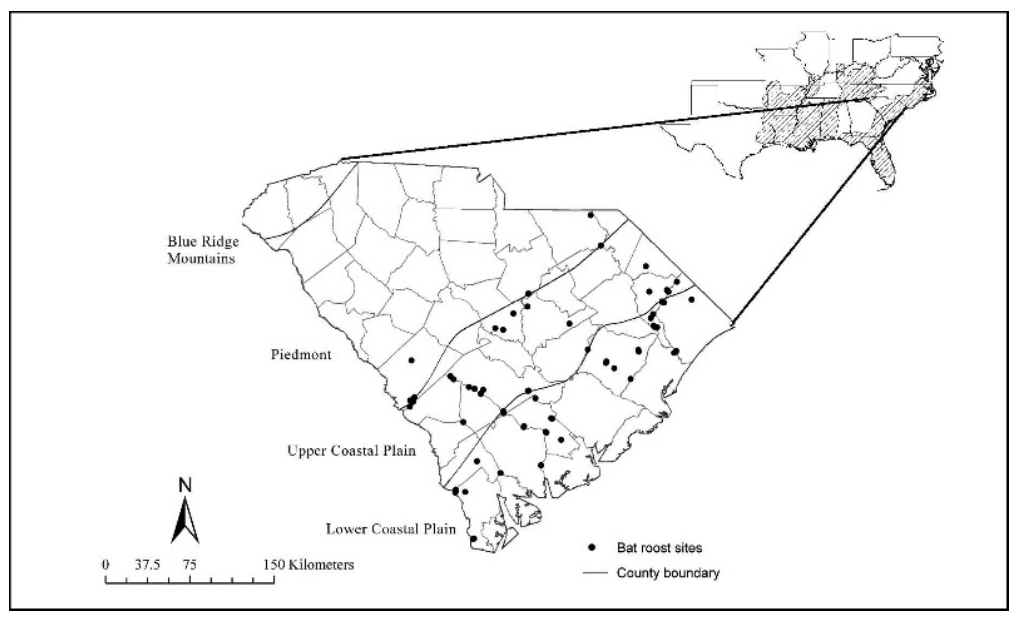

FIG. 1.-Upper right: range of Rafinesque's big-eared bats. Enlargement shows the four physiographic provinces of South Carolina and the locations of bridges used by Rafinesque's big-eared bats, late May through mid-Aug. 2002-2003

sampling), it has been difficult to estimate their relative abundance and determine their geographic distribution.

Historical accounts, museum specimens and incidental capture records place this species in the Blue Ridge Mountains, the Upper Coastal Plain and the Lower Coastal Plain physiographic regions in North Carolina, South Carolina and Georgia (Handley, 1959; Clark, 1990; Menzel et al., 2003). In the Carolinas, Rafinesque's big-eared bat is commonly associated with bottomland hardwood forests (Clark, 1990) which are most abundant within the Upper and Lower Coastal Plains (Conner, 1993). Although bottomland hardwood forests also occur in the Piedmont, this bat appears to be absent from this physiographic region (Menzel et al., 2003). It is not clear whether the Piedmont truly does not support populations of big-eared bats or whether there have been insufficient sampling efforts in this region. A reliable method for locating Rafinesque's big-eared bats is clearly needed to determine their population status and distribution.

Rafinesque's big-eared bats are non-migratory and use tree cavities, caves, mines, buildings and other man-made structures for roosting (Barbour and Davis, 1969). Like most cavity-roosting species, Rafinesque's big-eared bats that use tree cavities and bridges frequently switch roost sites (Lance et al., 2001; Trousdale and Beckett, 2005), whereas cave roosting Rafinesque's big-eared bats rarely switch roosts (Hurst and Lacki, 1999). In the Coastal Plains, naturally occurring structures include cavities in large diameter gum (Nyssa sp.) and cypress (Taxodium sp.) trees (Clark, 1990; Gooding and Langford, 2004; Trousdale and Beckett, 2005). Artificial sites are structurally similar to natural cavities, and include dimly lit areas in abandoned buildings, cisterns, wells and highway bridges (Barbour and Davis, 1969; Clark, 1990; Lance et al., 2001; Mirowsky et al., 2004; Trousdale and Beckett, 2002, 2004; Ferrara and Leberg, 2005a). Both artificial and natural structures are used as day and night roosts year-round, but frequency of use in anthropogenic structures peaks during May-Aug. when maternity colonies appear (Felts and Webster, 2003; Trousdale and Beckett, 2004). Thus, summer is the most appropriate time to conduct surveys in artificial structures, particularly bridges (Ferrara and Leberg, 2005b). 
The relative use of artificial versus natural structures may depend upon the availability of structures in each physiographic region. Rafinesque's big-eared bats more commonly roost in artificial structures in the southern portion of their range, and in natural roost sites in the northern portion of their range (Jones, 1977). The Coastal Plain lacks an abundance of natural roost sites (i.e., large trees) because many were harvested over a century ago. However, artificial structures now are widespread and are frequently used as roost sites. By contrast, in the northern portions of the range natural roost sites such as tree cavities, rock houses, abandoned mines and caves are more frequently used (Bunch et al., 1998; Hurst and Lacki, 1999), possibly because of their higher occurrence on the landscape.

Type of bridge construction is the strongest predictor of bridge occupancy by Rafinesque's big-eared bats (Lance et al., 2001; McDonnell, 2001; Trousdale and Beckett, 2002). Bats roost in the space between girders on the underside of bridges and have not been observed in enclosed and concealed expansion joints (Ferrara and Leberg, 2005a). In South Carolina, three main bridge types are present: flat-bottomed slab bridges, multi-beam (MB) girder bridges and T-beam (TB) cast-in-place girder bridges (L. R. Floyd, South Carolina Department of Transportation, unpubl.). MB bridges are variable in structure, but generally consist of parallel beams that span the entire length of the bridge and sometimes are referred to as I-beam or channel beam bridges. TB bridges also have parallel beams that span the entire length of the bridge, but the support beams are intersected at right angles by cross beams. Although Rafinesque's big-eared bats most frequently use girder bridges in Louisiana and North Carolina (Lance et al., 2001; McDonnell, 2001), it is not known whether they select either of the two girder type bridges found in South Carolina.

Most studies of bridge use by Rafinesque's big-eared bats have been conducted within relatively small geographic areas restricted to the Coastal Plain regions (Lance et al., 2001; McDonnell, 2001; Trousdale and Beckett, 2002; Felts and Webster, 2003). Limited bridge surveys have been conducted in South Carolina, but no day-roosting bats were found under the 44 bridges examined (Keeley and Tuttle, 1999). The objectives of our study were to: (1) document the use of bridges by Rafinesque's big-eared bats in South Carolina, (2) conduct a statewide bridge survey to determine their distribution across the state, (3) evaluate bridge attributes such as size and type that influence occupancy and (4) determine short term bridge fidelity and the number of visits needed to document presence. By identifying bridge types used by Rafinesque's big-eared bat and its fidelity to these structures, it may be possible to improve survey methods across its range.

\section{Methons}

STUDY AREA

South Carolina consists of four physiographic regions: the Blue Ridge Mountains, the Piedmont, the Upper Coastal Plain and the Lower Coastal Plain (Fig. 1). The climate of South Carolina is warm temperate to subtropical and is characterized by short, mild winters and long, hot and humid summers. Rainfall occurs throughout the year, but peak levels occur during the winter months in the mountains, and in Mar. and Jul. throughout the rest of the state. Average monthly rainfall amounts range from $11.4 \mathrm{~cm}$ to $17.3 \mathrm{~cm}$ in the mountains, $7.4 \mathrm{~cm}$ to $11.7 \mathrm{~cm}$ in the Piedmont and $6.0 \mathrm{~cm}$ to $16.6 \mathrm{~cm}$ in the Coastal Plains.

The Blue Ridge Mountain region, a part of the southern Appalachian Mountains, is situated in the upper northwestern portion of South Carolina. This region covers approximately $1.9 \%$ of the state, has a mountainous topography and ranges in elevation from 366 to 1067 m. Oak-hickory (Quercus sp. - Carya sp.), oak-pine (Quercus sp. Pinus sp.) 
and loblolly-shortleaf pine (P. taeda - P. echinata) are the dominant forest types (Conner, 1993).

The Piedmont region is adjacent to the Blue Ridge Mountains and covers $31.9 \%$ of South Carolina. It has a rolling topography and ranges in elevation from 91 to $366 \mathrm{~m}$. Urbanization and agriculture are common in this region; the dominant forests are loblollyshortleaf pine forests. Localized stands of mixed pine-hardwoods and bottomland hardwood forests consisting of oak-bald cypress-tupelo gum (Quercus sp. - Taxodium distichum - Nyssa sp.) trees also are found in the Piedmont, but are concentrated in areas adjacent to the Upper Coastal Plain (Conner, 1993).

The Upper and Lower Coastal Plain provinces cover the largest area of South Carolina (66.2\%), extending 193 to $241 \mathrm{~km}$ inland from the Atlantic Ocean. The topography of this region is flat; the highest elevation is $91 \mathrm{~m}$. Forests in both Coastal Plain regions are dominated by loblolly-shortleaf and longleaf-slash pine ( $P$. palustris - P. elliotti) forests; however, bottomland hardwood forests are more extensive in these physiographic provinces than any other in the state (Conner, 1993). The Upper Coastal Plain has comparatively more urban, agriculture and other non-forest cover types than the Lower Coastal Plain region.

\section{STATEWIDE BRIDGE SURVEY}

We conducted a county-by-county survey from 22 May to 8 Aug. 2002. Bridge data including structure type, construction material, latitude/longitude, feature crossed (i.e., waterway), unique identification number and bridge length and width were obtained from the South Carolina Department of Transportation (SC DOT; L. R. Floyd, South Carolina Department of Transportation, unpubl.). For each of the 46 counties in South Carolina, we grouped and surveyed bridges according to type (slab, MB and TB). Because bats rarely roost in bridges over roadways and train tracks (Erickson, 2002) we only surveyed bridges over water bodies. We surveyed bridges on public roads, including those on National Forests and National Wildlife Refuges. For safety reasons, we did not survey bridges on interstate highways. Each bridge was surveyed once.

For the first $9 \mathrm{~d}$ of the survey, we used a stratified random sampling design based on bridge type and inspected bridges in proportion to their occurrence. Slab bridges were the most common bridge type over water in South Carolina $(\mathrm{n}=4025)$, followed by MBs $(\mathrm{n}=$ 1616) and TBs $(n=676)$. Based on the results of this initial sampling period (Bennett, 2004) and data from previous studies (Lance et al., 2001; McDonnell, 2001), we modified the study design to increase the likelihood of locating bats under bridges. For the remainder of the survey, we inspected bridges in the following order of precedence: TB, MB, and slab. We attempted to inspect every $\mathrm{TB}$ bridge over water and simultaneously surveyed a randomly generated subset of $\mathrm{MB}$ and slab bridges.

We inspected the underside of each bridge during the day for presence of bats with 1,000,000 candle-power flashlights. Data collected included: date, county, latitude and longitude, physiographic region, bridge type and material, number of Rafinesque's bigeared bats present, number and species of other bats present, presence of bat feces and disturbance level. If bats were found under a bridge, we recorded details of the roost location and the group type (maternity colony or solitary). Where possible, independent counts of pups and adults were made by at least two field personnel and compared to ensure the most accurate count of bats. In some instances, total counts were not made to reduce disturbance to the bats. In these instances, we recorded an approximate range of the numbers of bats present. For data analysis, we used the lowest estimate. 
We rated disturbance beneath each bridge on a discrete scale of $0-3$. Bridges with no obvious disturbances were given a rating of 0 , low levels of disturbance were recorded as 1 , medium levels of disturbance were recorded as 2, and bridges with high levels of disturbance were given a rating of 3 . Disturbance factors included presence or evidence of humans such as trash, vandalism, footprints, all terrain vehicle tracks and heavy vehicular traffic on the surface of the structure.

2003 BRIDGE SURVEYS AND ROOST MONITORING

We conducted bridge surveys from 23 May to 1 Aug. 2003 using the same methods as in 2002. Although the 2003 field survey was similar in execution to the 2002 statewide survey, there were two important differences. First, we did not survey the entire state. Instead, we focused surveys in areas where big-eared bats were found in 2002. Second, we inspected bridges occupied in 2002 several times in 2003; most bridges with big-eared bats were surveyed every 2-3 wk so that bridges were examined up to five times. We also inspected additional bridges over water that were not visited in 2002, but were within occupied areas of the state. If a bridge was occupied in 2003 but not in 2002, we also monitored it regularly. However, due to restricted access, some bridges $(<10)$ were only inspected once in 2003.

\section{DATA ANALYSIS}

We used likelihood ratio chi-square tests (PROC FREQ; SAS, 2002) to determine the association between the presence of big-eared bats and qualitative attributes of bridges (type, physiographic region and disturbance) in 2002 and 2003. Due to small sample size, we used a Fisher's exact test to evaluate the association between the presence of big-eared bats and the occurrence of other bat species in 2002, and big-eared bat presence and disturbance in 2003 (Freeman and Halton, 1951). Associations between the presence of bats and quantitative attributes of bridges (length, width and area) were assessed using the Kruskall-Wallis one-way analysis of variance. We were unable to attain bridge size for 11 bridges in 2002 and eight bridges in 2003. Because of differences in sampling procedures between years, we analyzed data from 2002 and 2003 separately. Furthermore, because our sampling procedure was biased against slab bridges and no bats were found under these structures, we also ran the above analyses after excluding slab bridges from the dataset. We were unable to determine the association between bridge material (concrete, timber, steel alloy) and presence of bats because material and bridge type were not independent.

We used logistic regression analysis with a stepwise selection process $(\alpha=0.05)$ to determine bridge attributes selected or avoided by Rafinesque's big-eared bats (PROC LOGISTIC). We determined the goodness of fit of the logistic regression equations for binary response models (Hosmer and Lemeshow, 2000). Models were run with and without slab bridges. Because bridge area was highly correlated with bridge length $(r>0.95)$ it was not included in the models. We used an $\alpha \leq 0.05$ to determine statistical significance for all tests. Data are presented as the mean \pm sD throughout the results.

We used program PRESENCE (MacKenzie et al., 2002) to estimate the probability of detecting bats $(p)$ under a bridge and bridge occupancy $(\Psi)$ for the 2003 sampling period. We used estimates of $p$ to determine the minimum number of times a bridge needs to be inspected to determine whether it is occupied. However, because the bridges were not chosen randomly, $p$ and $\Psi$ are biased. Models were run on all bridges inspected once in 2002 and $\geq 2$ times in 2003. We included bridge use in 2002 as a covariate to test whether previous occupation of a bridge was an important variable in detection probabilities and occupancy in 2003. We compared models using Akaike's Information Criterion 
corrected for small sample sizes (AICc; Burnham and Anderson, 2002). Models with $\Delta_{\mathrm{i}}>2$ were not considered to have strong support. We estimated the minimum number of surveys needed to detect bats at a bridge using the following equation (MacKenzie and Royle, 2005):

$$
p *=1-(1-p)^{\mathrm{K}}
$$

where $p^{*}=$ the probability of finding bats at a bridge at least once, $p=$ the probability of detection, and $\mathrm{K}=$ the number of surveys.

\section{RESUlts}

\section{BRIDGE ROOSTS OF RAFINESQUE'S BIG-EARED BATS}

We surveyed 1129 bridges in 2002 and conducted 443 surveys of 235 bridges in 2003. Overall, we surveyed $7.1 \%$ of the slab bridges, $17.4 \%$ of the MB bridges and $83.4 \%$ of the TB bridges in the state, representing $17.9 \%$ of all bridges spanning permanent water bodies. We found Rafinesque's big-eared bats beneath 38 bridges (3.4\%) in 2002 and 54 bridges $(22.9 \%)$ in 2003. Many bridges were used in both years (see below); the total number of occupied bridges was 73. Colonies and solitary bats were sometimes found under the same bridge, but were always spatially separated. In 2002, we observed 196 big-eared bats in colonies ( $\mathrm{n}=13$ bridges) and 49 solitary bats $(\mathrm{n}=33$ bridges). Colonies observed in 2002 ranged in size from $2-53$ bats (median $=12$ bats). These numbers are conservative as it often was difficult to get an exact count of bats, particularly when neonates still clung to their mother. In 2003, colonies and solitary bats roosted beneath 24 and 47 bridges, respectively. The number of bats (range $=2-31$ bats) in colonies fluctuated throughout the 2003 monitoring period; the median number of bats in a group was eight. We found multiple roosts of solitary bats beneath nine bridges; one large bridge had five separate solitary big-eared bats roosting beneath it at one time.

In 2003, we were unable to inspect eight bridges occupied by solitary bats the previous year due to logistical and time constraints. We located Rafinesque's big-eared bats under an additional 35 bridges in 2003. Twenty-six of these bridges had been inspected in 2002 and did not have any day roosting big-eared bats, but 15 bridges (57.7\%) had feces in 2002.

Big-eared bats primarily roosted over the dry banks on either end of a bridge near the abutments; we found 4 of $108(3.7 \%)$ solitary bats roosting in the middle section of bridges where the waterbed was dry, and three of $37(8.2 \%)$ colonies over both water and dry bank under bridges where there was little dry substrate present. Rafinesque's big-eared bats roosted between support beams in the moderately open areas of a bridge; they were never found in small expansion joints. Bats occasionally flew to adjacent sections of the bridge during surveys; however, bats were only observed leaving bridges twice during the study. Rafinesque's big-eared bats did not leave fecal stains on the bridge walls. Fecal pellets were most often observed as individual pieces on the concrete walls of the bridges; occasionally we found guano in larger quantities on the ground.

We observed other bat species beneath 45 bridges during the statewide survey: eastern pipistrelle (Perimyotis subflavus; $\mathrm{n}=26$ ); big brown bat (Eptesicus fuscus; $\mathrm{n}=10$ ); southeastern myotis (Myotis austroriparius; $\mathrm{n}=1$ ); Brazilian free-tailed bat (Tadarida brasiliensis; $\mathrm{n}=1)$; and unidentified Myotis species $(\mathrm{n}=7)$. Solitary big-eared bats roosted under bridges with birds $(n=7)$ and other bat species $(n=3)$, but did not roost under bridges where domestic animals were found. When Rafinesque's big-eared bats used the same bridge as other species, they usually used separate sections of a bridge. However, we 
TABLE 1.-Numbers and percentages (in parentheses) of bridges surveyed in South Carolina occupied by Rafinesque's big-eared bats and other species of bats, May-Aug. 2002. $n=$ number of bridges examined

\begin{tabular}{lrrr}
\hline \hline \multicolumn{1}{c}{ Bridge variable } & $\mathrm{n}$ & Rafinesque's big-eared bats & Other bat spp. \\
\hline Type & & & \\
$\quad$ Slab & 284 & $0(0.0)$ & $0(0.0)$ \\
Multi-Beam & 281 & $6(2.1)$ & $15(5.3)$ \\
$\quad$ T-Beam & 564 & $32(5.7)$ & $28(5.0)$ \\
Material & & & \\
$\quad$ Concrete & 1015 & $38(3.9)$ & $41(4.0)$ \\
Steel & 87 & $0(0.0)$ & $2(2.3)$ \\
Timber & 27 & $0(0.0)$ & $0(0.0)$ \\
Disturbance & & $3(0.9)$ & $14(4.4)$ \\
0 & 318 & $12(3.2)$ & $19(5.0)$ \\
1 & 381 & $18(6.6)$ & $9(3.3)$ \\
2 & 275 & $5(3.2)$ & $1(0.7)$ \\
3 & 155 & & $2(0.0)$ \\
Region & & $2(0.5)$ & $23(6.0)$ \\
Blue Ridge & 32 & $23(4.6)$ & $16(3.2)$ \\
Piedmont & 381 & $13(6.1)$ & $2(0.9)$ \\
Upper Coastal Plain & 502 & & \\
Lower Coastal Plain & 214 & &
\end{tabular}

located one maternity colony of big-eared bats $(\mathrm{n}=37$ bats) roosting next to a maternity group of big brown bats $(n=6$ bats) on a single occasion in 2003 . We regularly found both species beneath this bridge.

\section{USE OF BRIDGES BY PHYSIOGRAPHIC REGION}

Bridges used by Rafinesque's big-eared bats in 2002 were not distributed evenly across the state (Fig. 1, Table 1). Although the majority of big-eared bat roosts (94.7\%) were beneath bridges in the Upper and Lower Coastal Plains, a small percentage $(5.3 \%)$ were located in the Piedmont. No bridges in the Blue Ridge Mountains were used by bats. We found a significant association between physiographic region and presence of Rafinesque's bigeared bats $\left(\chi^{2}=22.7\right.$, $\left.\mathrm{df}=3, \mathrm{P} \leq 0.001, \mathrm{n}=1129\right)$ in 2002. However, we did not find significant differences in the presence of bats between Upper and Lower Coastal Plain regions in $2002\left(\chi^{2}=0.7, \mathrm{df}=1, \mathrm{P}=0.411, \mathrm{n}=716\right)$ or $2003\left(\chi^{2}=1.9, \mathrm{df}=1, \mathrm{P}=0.169, \mathrm{n}\right.$ $=235)$. We established new county records for Rafinesque's big-eared bats in Allendale, Bamberg, Barnwell, Chesterfield, Dillon, Horry, Marion, Orangeburg, Sumter and Williamsburg counties.

In the Coastal Plain, many of the bridge roost sites were grouped within the same watershed (Fig. 1). The South Fork of the Edisto River and its tributaries, which cross both the Upper and Lower Coastal Plain in the western part of South Carolina, contained the highest concentration of occupied bridges (23.3\%). In addition, we found $12.3 \%$ of the bridge roosts along the Great Pee Dee River in the eastern portion of the state.

\section{BRIDGE ATTRIBUTES ASSOCIATED WITH ROOST SELECTION}

In 2002, the presence of Rafinesque's big-eared bats was associated with bridge type $\left(\chi^{2}=\right.$ 28.6, $\mathrm{df}=2, \mathrm{P} \leq 0.001, \mathrm{n}=1129)$, disturbance $\left(\chi^{2}=14.8, \mathrm{df}=3, \mathrm{P}=0.002, \mathrm{n}=1129\right)$, bridge length $\left(\chi^{2}=17.35\right.$, $\left.\mathrm{df}=1, \mathrm{P} \leq 0.0001, \mathrm{n}=1120\right)$, width $\left(\chi^{2}=12.56\right.$, df $=1, \mathrm{P} \leq$ 


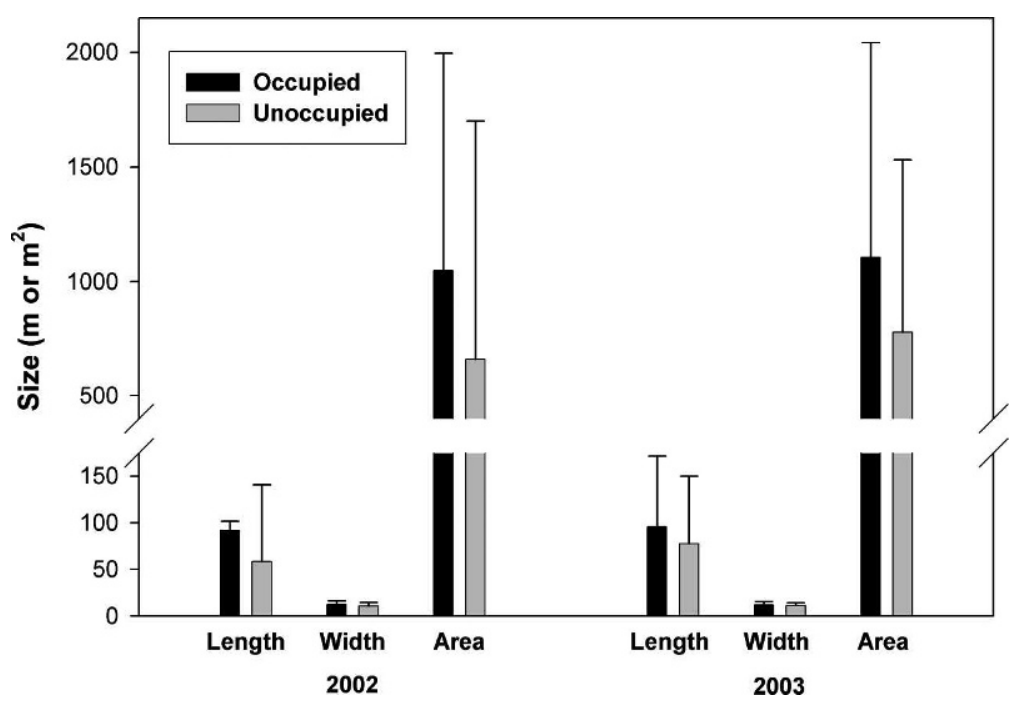

Fig. 2.-Mean length, width and area of occupied and unoccupied bridges by Rafinesque's big-eared bats in South Carolina May-Aug. 2002 and 2003. Error bars represent 1 SD

$0.0001, \mathrm{n}=1120)$ and area $\left(\chi^{2}=23.20, \mathrm{df}=1, \mathrm{P} \leq 0.0001, \mathrm{n}=1120\right)$. We only located Rafinesque's big-eared bats beneath TB and MB bridges; no bats were observed under slab bridges (Table 1). When slab bridges were excluded from the analyses, similar results were obtained: presence of big-eared bats was associated with bridge type $\left(\chi^{2}=6.2\right.$, df $=1, \mathrm{P}=$ $0.013, \mathrm{n}=845)$, disturbance $\left(\chi^{2}=9.8, \mathrm{df}=3, \mathrm{P}=0.02, \mathrm{n}=845\right)$, length $\left(\chi^{2}=9.67, \mathrm{df}=1\right.$, $\mathrm{P}=0.002, \mathrm{n}=842)$, width $\left(\chi^{2}=9.22, \mathrm{df}=1, \mathrm{P}=0.002, \mathrm{n}=842\right)$ and area $\left(\chi^{2}=15.18, \mathrm{df}\right.$ $=1, \mathrm{P}<0.002, \mathrm{n}=842)$. The presence of other bat species was not associated with roosting big-eared bats $(\mathrm{P}=0.120)$. Occupied bridges had a median disturbance level of 2 . In general, we found bats under large girder bridges that were $36.4 \%$ longer, $13.7 \%$ wider, and covered $37.2 \%$ more area than bridges not occupied (Fig. 2). All occupied bridges were concrete.

Results of the logistic regression analysis for bridge selection in 2002 indicated that physiographic region $\left(\chi^{2}=24.5, \mathrm{df}=2, \mathrm{P} \leq 0.0001\right)$, bridge type $\left(\chi^{2}=20.1, \mathrm{df}=1, \mathrm{P} \leq\right.$ $0.0001)$ and bridge width $\left(\chi^{2}=5.2, \mathrm{df}=1, \mathrm{P}=0.023\right)$ were the best predictors of big-eared bat presence. The overall regression equation was significant $\left(\chi^{2}=57.8, \mathrm{df}=3, \mathrm{P} \leq 0.001\right)$ and the model did not deviate from a logistic fit $\left(\chi^{2}=6.1 \mathrm{df}=8, \mathrm{P}=0.637\right)$. Interactions between variables were not significant and were removed from the final model. Although bridge length and disturbance differed significantly between occupied and unoccupied bridges in the univariate analyses, they did not enter the model indicating no influence on selection of bridge roosts when the other variables were controlled. We obtained similar results when we excluded slab bridges from the analyses. Presence of big-eared bats was influenced by physiographic region $\left(\chi^{2}=28.8\right.$, df $\left.=1, \mathrm{P}<0.0001\right)$, bridge type $\left(\chi^{2}=4.2\right.$, $\mathrm{df}=1, \mathrm{P}=0.04)$ and bridge width $\left(\chi^{2}=5.1\right.$, $\left.\mathrm{df}=1, \mathrm{P}=0.02\right)$. The overall model was significant $\left(\chi^{2}=42.7, \mathrm{df}=3, \mathrm{P}<0.0001\right)$ and did not deviate from a logistic fit $\left(\chi^{2}=12.8\right.$, $\mathrm{df}=8, \mathrm{P}=0.117)$.

In 2003, presence of bats was significantly associated with bridge type and disturbance level. As in 2002, we found Rafinesque's big-eared bats only beneath TB and MB bridges 
TABLE 2.-Number and percentage (in parentheses) of highway bridges in the Upper and Lower Coastal Plains of South Carolina occupied by Rafinesque's big-eared bats, May-Aug. 2003. n = number of bridges examined

\begin{tabular}{lrc}
\hline \hline \multicolumn{1}{c}{ Bridge variable } & $\mathrm{n}$ & Rafinesque's big-eared bats \\
\hline Type & & \\
$\quad$ Slab & 11 & $0(0.0)$ \\
Multi-Beam & 38 & $7(18.4)$ \\
T-Beam & 187 & $47(25.0)$ \\
Disturbance & & \\
0 & 130 & $29(22.3)$ \\
1 & 86 & $24(27.9)$ \\
2 & 13 & $1(7.7)$ \\
3 & 7 & $0(0.0)$ \\
Region & & $32(26.7)$ \\
Upper Coastal Plain & 120 & $22(19.0)$ \\
Lower Coastal Plain & 116 & \\
\hline
\end{tabular}

(Table 2). There was a significant association between structure type and occupancy $\left(\chi^{2}=\right.$ $6.8, \mathrm{df}=2, \mathrm{P}=0.034, \mathrm{n}=235)$. Although $\mathrm{TB}$ bridges were $>6$ times more likely to be used than MB bridges, there was no statistical difference in occupancy between MB and TB in $2003\left(\chi^{2}=0.8, \mathrm{df}=1, \mathrm{P}=0.357, \mathrm{n}=224\right)$. Most big-eared bats used bridges with a disturbance level of 0 or 1 in 2003, and there was a significant association between disturbance level and bat presence $(\mathrm{P}=0.001, \mathrm{n}=235)$.

Bridges occupied by big-eared bats in 2003 were longer $\left(\chi^{2}=8.7, \mathrm{df}=1, \mathrm{P}=0.003, \mathrm{n}=\right.$ $227)$ and had greater area $\left(\chi^{2}=11.9, \mathrm{df}=1, \mathrm{P}=0.0006, \mathrm{n}=227\right)$ than unoccupied bridges (Fig. 2). Width did not differ significantly between occupied and unoccupied bridges $\left(\chi^{2}=\right.$ 3.6 , $\mathrm{df}=1, \mathrm{P}=0.06)$. Bridge type was the only variable that entered into the logistic regression model $\left(\chi^{2}=5.9, \mathrm{df}=1, \mathrm{P}=0.02\right)$.

\section{ROOST FIDELITY AND PROBABILITY OF DETECTION}

We visited occupied bridges an average of 3.06 times (range 1-5) and unoccupied bridges 2.0 times (range 1-5) during the 2003 survey. For bridges that were occupied at least once and inspected more than once, the frequency of bridge use ranged from $33 \%$ to $100 \%$ $($ mean $=65.9 \% \pm 24.7 \%)$. For all bridges (occupied and unoccupied) inspected more than once, frequency of use was $24.7 \pm 35.8 \%$. Of the 30 bridges occupied in 2002 and surveyed in 2003, $19(63.3 \%)$ were occupied both years.

Bridge use in 2002 affected both detection probability and occupancy in 2003 (Table 3). Probability of detecting Rafinesque's big-eared bats under bridges in 2003 that were not

TABLE 3.- Model selection results for probability of detection and occupancy by Rafinesque's bigeared bats under bridges in the Upper and Lower Coastal Plains of South Carolina, May-Aug. 2003. Occupancy $(\Psi)$ and probability of detection $(p)$ were modeled with or without consideration of whether the bridge was occupied in 2002 (Occ02). (.) indicates that Occ02 was held constant

\begin{tabular}{lccc}
\hline \multicolumn{1}{c}{ Model } & $\mathrm{K}$ & AICc & $\Delta$ AICc \\
\hline$\Psi($ Occ02) $p($ Occ02) & 4 & 303.10 & 0 \\
$\Psi() p.($ Occ02) & 3 & 307.09 & 3.99 \\
$\Psi($ Occ02) $p()$. & 3 & 308.54 & 5.44 \\
$\Psi() p.()$. & 2 & 320.54 & 17.44 \\
\hline
\end{tabular}




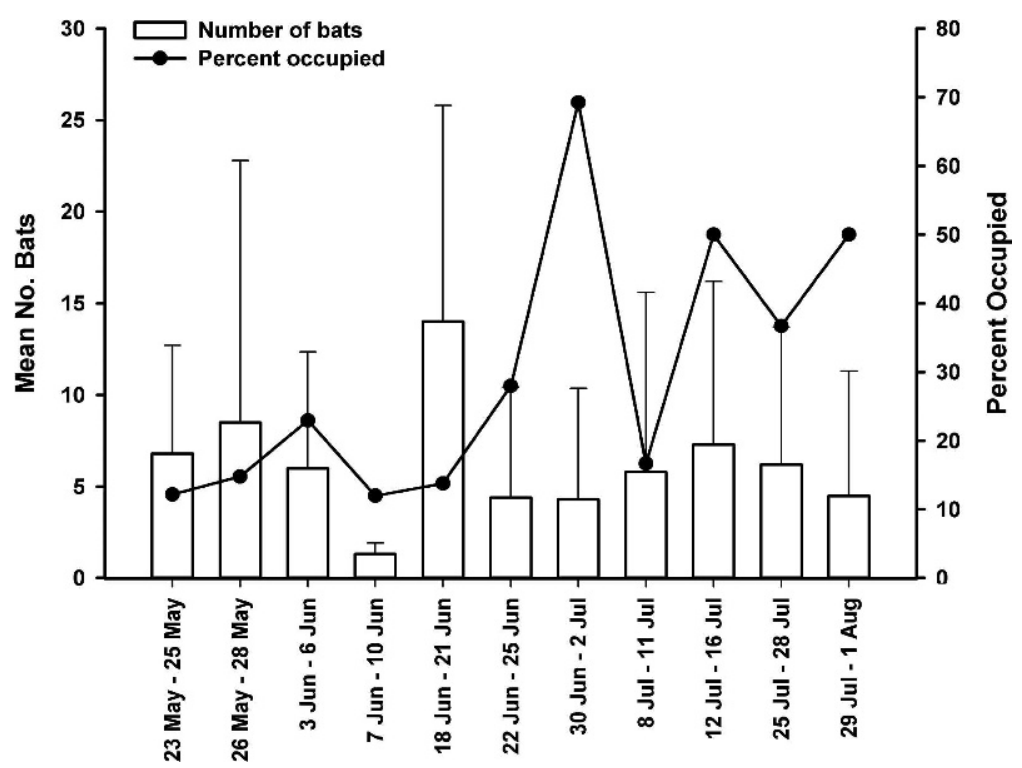

Fig. 3.-Mean number of Rafinesque's big-eared bats under bridges and the percent of bridges occupied in the Coastal Plain of South Carolina from late May through early Aug., 2003. Error bars represent $1 \mathrm{sD}$

used in 2002 was 0.457 and occupancy was 0.385 . In contrast, $p$ for bridges that had bats in 2002 was 0.730 and occupancy was 0.727 . Thus, if bats were not observed under a bridge in 2002, there was a $91 \%$ chance of detecting bats under the same bridge in 2003 if they were inspected four times and a $95 \%$ chance of detecting them if they were inspected five times. By contrast, if bats were observed under a bridge in 2002, there was a $93 \%$ chance of detecting them in 2003 if the bridge was inspected only twice and a $98 \%$ chance of detecting them if it was inspected three times.

\section{SEASONAL BRIDGE USE}

The highest mean number of bats per occupied bridge (14.0 \pm 11.8 bats) was observed in mid-Jun. (Fig. 3). However, we recorded the highest percent of occupied bridges $(69.2 \%)$ in early Jul. In general, although the mean number of bats per occupied bridge was similar throughout the 2003 survey period, we found more occupied bridges during the latter part of the survey.

\section{Discussion}

Our study represents the most extensive regional bridge survey conducted for Rafinesque's big-eared bats. Although only a small proportion of the state's bridges were occupied, they were occupied by both maternity colonies and solitary bats, and were used over multiple years. However, use of bridges was not distributed randomly with respect to region, bridge type or size. Bats selected large girder bridges, primarily in the Upper and Lower Coastal Plains. Results from the logistic regression analysis indicated the importance of physiographic region and bridge type to the bat's distribution and selection of roosts. 
The distribution of Rafinesque's big-eared bats under bridges in South Carolina was similar to historical records for this species (Menzel et al., 2003). Although new occurrence records were obtained for 10 counties, they were all within the bat's previously described range. The majority of bridges used as big-eared bat day roosts were located in the Upper and Lower Coastal Plains. However, two bridge roosts were located in the Piedmont. Both bridges contained solitary bats and were located $<30 \mathrm{~km}$ from the Upper Coastal Plain within bottomland deciduous forests, the bat's primary roosting habitat in the Coastal Plain (Clark, 1990; Lance et al., 2001; Trousdale and Beckett, 2005). Thus, it appears that Rafinesque's bigeared bats are largely absent from the Piedmont of South Carolina, but use localized tracts of bottomland hardwood forest that are contiguous with those of the Coastal Plain.

It is unlikely that we failed to locate a significant population of Rafinesque's big-eared bats in the Piedmont. Although bottomland hardwood forests and large cavity forming trees are present in this physiographic region, they are uncommon. However, suitable bridges for roosting are plentiful (275 TB bridges and $1188 \mathrm{MB}$ bridges). Thus, if bats were present they would be expected to be beneath bridges. Although we determined that at least two to five surveys are necessary to determine whether a bridge is being used, we used the same sampling method (i.e., one survey per bridge) in the Coastal Plains and located bats under 36 bridges.

The lack of occupied bridges in the Blue Ridge Mountains was surprising. Rafinesque's big-eared bats were captured and observed in this region during the time of the survey by two of the authors (SCL, MSB) thus, we expected to find them using bridges. However, the Blue Ridge region has fewer suitable bridges (only 25 TB bridges and 5 MB bridges) than the Coastal Plain (376 TB bridges and 332 MB bridges). Thus, if bats used bridges at the same rate in the Blue Ridge as in the Coastal Plain, they only would be expected to occupy one bridge. Moreover, use of artificial roosts appears to be rare in the northern portion of the range (Jones, 1977). Although a maternity colony was observed under one bridge in Kentucky (James Kiser, in litt.), no Rafinesque's big-eared bats were found under 232 bridges in southern Illinois (Feldhamer et al., 2003). Thus, bridge use may be rare in the northern portion of the range, perhaps because natural roost sites such as rock houses, caves, tree cavities and abandoned mines are still abundant. Moreover, because a large percentage $(>60 \%)$ of the Blue Ridge Mountains is protected through state conservation programs or is in federal ownership, natural roost sites may be more available than in other parts of South Carolina.

We found a strong relationship between presence of Rafinesque's big-eared bats and bridge type. Results of the logistic regression analysis indicated the odds of locating bigeared bats were highly dependent upon bridge structure. Although we only examined a small proportion of the slab bridges in the state, we found no evidence of use of these bridges by Rafinesque's big-eared bats or other species. Our observations are consistent with the pattern of bridge use by Rafinesque's big-eared bats in other states. In Louisiana, approximately 97\% of Rafinesque's big-eared bat observations were from girder type bridges (Lance et al., 2001) and in the Coastal Plain of North Carolina 100\% of the Rafinesque's bigeared bat observations from girder bridges (McDonnell, 2001).

Although many of our findings were similar to previous studies, we found some unique patterns of bridge selection in this study. Rafinesque's big-eared bats showed a higher rate of occupancy in TB bridges $(9.1 \%, \mathrm{n}=31$ of 341 TB bridges; Upper and Lower Coastal Plains only) than MB bridges (3.2\%, $\mathrm{n}=5$ of 155 bridges; Upper and Lower Coastal Plains only) in South Carolina. However, in the Coastal Plains of North Carolina, the rate of occupancy was higher beneath MB bridges $(16.6 \%, \mathrm{n}=29$ of $259 \mathrm{MB}$ bridges $)$ than TB bridges $(9.0 \%, \mathrm{n}=$ 
6 of 67 TB bridges; McDonnell, 2001). In addition, big-eared bats used a small number of timber MB bridges in North Carolina (5.0\%, $\mathrm{n}=6$ of 120 bridges; McDonnell, 2001); no timber bridges were occupied in either year of the South Carolina survey ( 0 of 27 bridges). Differences in the use of $\mathrm{MB}$ versus $\mathrm{TB}$ bridges may be related to other bridge variables such as surrounding habitat and roost microclimate, which are significant factors in the selection of roosts by Rafinesque's big-eared bats (Clark, 1990; Lacki, 2000; Lance et al., 2001). Measurement of these extrinsic variables may help to resolve the difference in bridge use patterns within the Coastal Plain.

Occupancy of larger bridges also was unique to Rafinesque's big-eared bats in South Carolina. Bridge use in Louisiana and North Carolina was not related to length or width (Lance et al., 2001; McDonnell, 2001), but in South Carolina, occupied bridges were longer, wider and covered a larger area than bridges not occupied. Bridge size is a significant factor in night roost selection for many bats in western North America (Perlmeter, 1996; Adam and Hayes, 2000). Larger bridges maintain higher nighttime temperatures thus, provide a better microclimate than smaller bridges. Higher nighttime temperatures may be a particularly significant factor for maternity colonies during the lactation period when females leave their young to forage (e.g., Chruszcz and Barclay, 2002). Larger bridges also may provide a greater diversity of microclimates, allowing bats to choose among them as environmental conditions change, as well as providing greater protection from predators (Ferrara and Leberg, 2005a).

Disturbance was a significant variable in roost selection by bats, but was inconsistent between years. In the 2002 statewide survey, bridges with a disturbance rating of 2 were more likely to be occupied than any other bridges. In 2003, most occupied bridges had a disturbance rating of 0 . The difference between years was probably due to variation among observers. The apparent occupation of bridges with a high level of disturbance in 2002 is in disagreement with other studies (Lacki, 1998, 2000; Lance et al., 2001), likely because disturbance caused by traffic on bridge surfaces and the disturbance levels underneath a bridge were not separated in our study. Often, bridges with heavy traffic levels had little disruption underneath the structure; this may account for the occupation of bridges with seemingly elevated disturbance in 2002.

Rafinesque's big-eared bats exhibited high short-term fidelity to bridges in the Coastal Plains of South Carolina. For structures occupied at least once, the frequency of use was $65.9 \%$. Although this estimation of bridge roost fidelity may be somewhat biased because bridges were inspected more often if bats initially were present, the frequency of bridge use was similar to other studies. Lance et al. (2001) reported that female big-eared bats primarily used bridges, but that the proportion of days spent at a bridge roost varied from $20 \%$ to $100 \%$. The remaining roost days were spent in trees (Nyssa spp.). Ferrara and Leberg (2005b) also found high short-term fidelity to bridge roosts by tagged individuals. We found that the probability of finding bats under a bridge and bridge occupancy in 2003 were strongly associated with presence of bats under the bridge in 2002. This indicates there was strong year-to-year fidelity to bridges. High roost fidelity is directly related to the permanency of a structure and inversely related to roost availability (Lewis, 1995). Bridges are permanent, available and abundant in South Carolina, so the high fidelity of Rafinesque's big-eared bats to bridges is not surprising.

Our results suggest that large-scale bridge surveys may be a good method for determining the distribution of Rafinesque's big-eared bats across a region, as well as for locating local colonies and individuals. While surveys can be conducted throughout the summer, Jul. represents the time when the most bridges were occupied. Further, young Rafinesque's big- 
eared bats are independent by early Jul. (Jones and Suttkus, 1975) thus, disturbance of maternity colonies should be reduced during this time. Although surveying bridges once is sufficient for determining large-scale distribution patterns, multiple surveys are necessary to determine whether a particular bridge is occupied by bats. Our estimates of $p$ and $\Psi$ in 2003 were biased because we did not select bridges at random. Thus, our estimates of the number of times that bridges should be inspected represent the lowest end of the range. However, based on our estimates, a bridge should be inspected at least four or five times during the summer if there is no indication of prior use and at least two times if the bridge was used in the prior year to determine whether it is currently being used. Ferrara and Leberg (2005b) suggested that bridges be inspected $\geq 3$ times to ensure that a known roost is not being occupied. However, we suggest that further studies be conducted using repeat visits of randomly selected bridges to obtain unbiased estimates of the minimum number of surveys necessary to determine whether a bridge is being occupied by Rafinesque's big-eared bats.

Acknowledgments. - Financial and logistical support for this research was provided by the U.S. Fish and Wildlife Service's Candidate Conservation program, the South Carolina Department of Natural Resources and the USDA Forest Service Southern Research Station. We thank A. Trousdale and two anonymous reviewers for valuable comments and M. Collingwood, C. Dachelet, D. Eggert A. Elzerman, J. Schwenter and A. Sjollema for field assistance. Thanks to W. Bridges for help with statistical analyses.

\section{Literature Cited}

Adam, M. D. and J. P. Hayes. 2000. Use of bridges as night roosts by bats in the Oregon coast range. J. Mammal., 81:402-407.

Barbour, R. and W. Davis. 1969. Bats of America. University Press of Kentucky, Lexington, Kentucky. $286 \mathrm{p}$.

BenNetT, F. M. 2004. A survey of the statewide distribution and variation in metal concentrations from the hair of Rafinesque's big-eared bats (Corynorhinus rafinesquii) in South Carolina. Thesis, Clemson University, Clemson, South Carolina, USA. 121 p.

Bunch, M. J., J. Sorrow And A. S. Dye. 1998. Rafinesque's big-eared bat surveys and prelisting recovery. Unpublished Final Report for the U.S. Fish and Wildlife Service by the South Carolina Department of Natural Resources, $82 \mathrm{p}$.

Burnham, K. P. And D. R. Anderson. 2002. Model selection and multi-model inference. Springer, New York. 488 p.

Chruszcz, B. J. and R. M. R. Barclay. 2002. Thermoregulatory ecology of a solitary bat, Myotis evotis, roosting in rock crevices. Funct. Ecol., 16:18-26.

Clark, M. K. 1990. Roosting ecology of the eastern big-eared bat (Plecotus rafinesquii), in North Carolina. Thesis, North Carolina State University, Raleigh, USA. 111 p.

Conner, R. C. 1993. Forest Statistics for South Carolina. USDA Forest Service, Southeastern Forest Experiment Station Resource Bulletin SE-141. 52 p.

Erickson, G. A. 2002. Bat and Bridges Technical Bulletin (Hitch Hikers Guide to Bat Roosts). California Dept. Transportation, Sacramento, CA. 2002. 76 p.

Feldhamer, G. A., T. C. Carter, A. T. Morzillo and E. H. Nicholson. 2003. Use of bridges as day roosts by bats in southern Illinois. Trans. Ill. State Acad. Sci., 96:107-112.

Felts, J. W. And W. D. Webster. 2003. The use of bridges as daytime roosts by bats in southeastern North Carolina. J. No. Car. Acad. Sci., 119:172-178.

Ferrara, F. J. And P. L. Leberg. 2005a. Characteristics of positions selected by day-roosting bats under bridges in Louisiana. J. Mammal., 86:729-735.

AND - 2005b. Influence of investigator disturbance and temporal variation on surveys of bats roosting under bridges. Wildl. Soc. Bull., 33:1113-1122.

Freeman, G. H. and J. H. Halton. 1951. Note on an exact treatment of contingency, goodness of fit and other problems of significance. Biometrika, 38:141-149. 
Gooding, G. AND J. R. LANGFord. 2004. Characteristics of tree roosts of Rafinesque's big-eared bat and southeastern bat in northeastern Louisiana. Southwest. Nat., 49:61-67.

Handley, C. O., JR. 1959. A revision of American bats of the genera Euderma and Plecotus. Proc. U.S. Nat. Mus., 110:95-246.

Harvey, M. J., J. S. Altenbach and T. L. Best. 1999. Bats of the United States, Arkansas Game \& Fish Commission. 64 p.

Hosmer, D. W., JR. And S. Lemeshow. 2000. Applied Logistic Regression, second edition. John Wiley and Sons, New York, New York. 392 p.

Hurst, T. E. AND M. J. LACKI. 1999. Roost selection, population size and habitat use by a colony of Rafinesque's big-eared bats (Corynorhinus rafinesquii). Amer. Midl. Nat., 142:363-371.

Jones, C. 1977. Plecotus rafinesquii. Mammal. Species, 69:1-4.

AND R. D. SutTkus. 1975. Notes on the natural history of Plecotus rafinesquii. Occ. Papers Mus. Zool., Louisiana State Univ., 47:1-13.

Keeley, B. W. and M. D. Tuttle. 1999. Bats in American bridges. Resource Publication No. 4. Bat Conservation International, Austin, Texas.

LACKI, M. J. 1998. Monitoring of Virginia big-eared bats and Rafinesque's big-eared bats at Hood Branch Rock Shelter, Natural Bridge State Park Nature Preserve, Powell County, Kentucky. Kentucky State Nature Preserve Commission, Frankfort, Kentucky.

2000. Effect of trail users at a maternity roost of Rafinesque's big-eared bats. J. Cave and Karst Stud., 62:163-168.

Lance, R. F., B. T. Hardcastle, A. Talley and P. L. Leberg. 2001. Day-roost selection by Rafinesque's bigeared bats (Corynorhinus rafinesquii) in Louisiana forests. J. Mammal., 82:166-172.

LewIS, S. E. 1995. Roost fidelity of bats: A review. J. Mammal., 76:481-196.

Mackenzie, D. I., J. D. Nichols, G. B. Lachman, S. Droege, J. A. Royle and C. A. Langtimm. 2002. Estimating site occupancy rates when detection probabilities are less than one. Ecology, 83:2248-2255.

- AND A. RoyLe. 2005. Designing occupancy studies: general advice and allocating survey effort. $J$. Appl. Ecol., 42:1105-1114.

Martin, C. O., W. A. Mitchell and M. S. Wolters. 2002. Eastern cave- and crevice-dwelling bats potentially impacted by U.S. Army Corp of Engineers reservoir operations. EMRRP Technical Notes Collection (ERDC TN EMRRP-SI-24). U.S. Army Engineer Research and Development Center, Vicksburg, Mississippi, USA.

McDonnell, J. M. 2001. Use of bridges as day roosts by bats in the North Carolina Coastal Plain. Thesis, North Carolina State University, Raleigh, North Carolina, USA. 74 p.

Menzel, J. M., M. A. Menzel, W. M. Ford, J. W. Edwards, S. R. Sheffield, J. C. Kilgo and M. S. Bunch. 2003. The distribution of the bats of South Carolina. Southeast. Nat., 2:121-152.

Mirowsky, K. M., P. A. Horner, R. W. Maxey and S. A. Sмith. 2004. Distributional records and roosts of southeastern myotis and Rafinesque's big-eared bat in eastern Texas. Southwest. Nat., 49:294-298.

Perlmeter, S. I. 1996. Bats and bridges: patterns of night roosting activity in the Willamette National Forest, p. 132-150. In: R. M. R. Barclay and R. M. Brigham (eds.). Proceedings of the bats and forests symposium, Oct. 19-21, 1995. British Columbia Ministry of Forests Research Branch, Victoria, British Columbia. 292 p.

SAS InstituTE. 2002. SAS user's guide. Version 9.0. SAS Institute, Cary, North Carolina, USA.

Trousdale, A. W. and D. C. Beckett. 2002. Bats (Mammalia: Chiroptera) recorded from mist-net and bridge surveys in southern Mississippi. J. Miss. Acad. Sci., 47:183-189. AND — 2004. Seasonal use of bridges by Rafinesque's big-eared bat, Corynorhinus rafinesquii, in southern Mississippi. Southeast. Nat., 3:103-112.

AND - 2005. Characteristics of tree roosts of Rafinesque's big-eared bat, Corynorhinus rafinesquii, in southeastern Mississippi. Amer. Midl. Nat., 154:442-449. 